\section{- MEDICAL SCANS}

A major, and increasing, source of lowdose radiation comes from the medical world, says David Richardson, an epidemiologist at the University of North Carolina and an author of the study. "The amount of radiation a US person receives in a year on average has doubled, mostly because of medical procedures," he says (see 'Rising background'). Computed-tomography (CT) scans are to blame for most of the rise; a typical abdominal scan delivers more than $10 \mathrm{mSv}$. Radiologist David Brenner of Columbia University in New York has calculated that of the 25 million people having CT scans in a year, 1 million will have accumulated more than $250 \mathrm{mSv}$ over the previous 20 years.

One group that needs to pay particular attention to the findings are the tens of thousands of health workers who use radiological imaging to guide catheters through blood vessels of patients to reach into their hearts and brains, says Martha Linet, at the US National Cancer Institute's radiation epidemiology programme in Bethesda, Maryland. These minimally invasive operative procedures are used ever more frequently, she says.

Epidemiological studies suggest that radiation exposure has health effects beyond cancer. The IARC-led consortium is now looking at the effect on solid cancers, and also on diseases such as heart attack and stroke. Other studies are under way to study the long-term impact of low-dose radiation on different cohorts. One, the Epi-CT study, is recruiting one million people from nine European countries who had CT scans as children; its analysis will be complete by 2017 . In another, the Helmholtz Center Munich is analysing heart tissue from workers who died in the Mayak uranium mines in the South Urals, Russia.

Although the European Commission has been funding research on low-dose radiation for some time, equivalent programmes in the United States have stalled. In 2013, scientists wrote an open letter to the White House Office of Science and Technology Policy calling for renewed investment, and a bill is currently being debated in Congress calling for more work.

Getting funding for such studies is important, says Mike Atkinson, head of radiation biology at the Helmholtz Center Munich. Being able to quantify the effects of radiation will help doctors to balance risk against benefit when deciding whether to put children in CT scanners, he says. And further understanding the health impacts of low-dose radiation might aid decisions about how much remedial activity is needed to clean up soil contaminated by radioactivity from accidents or nuclear-power works, says Morgan. $\mathbf{\square}$

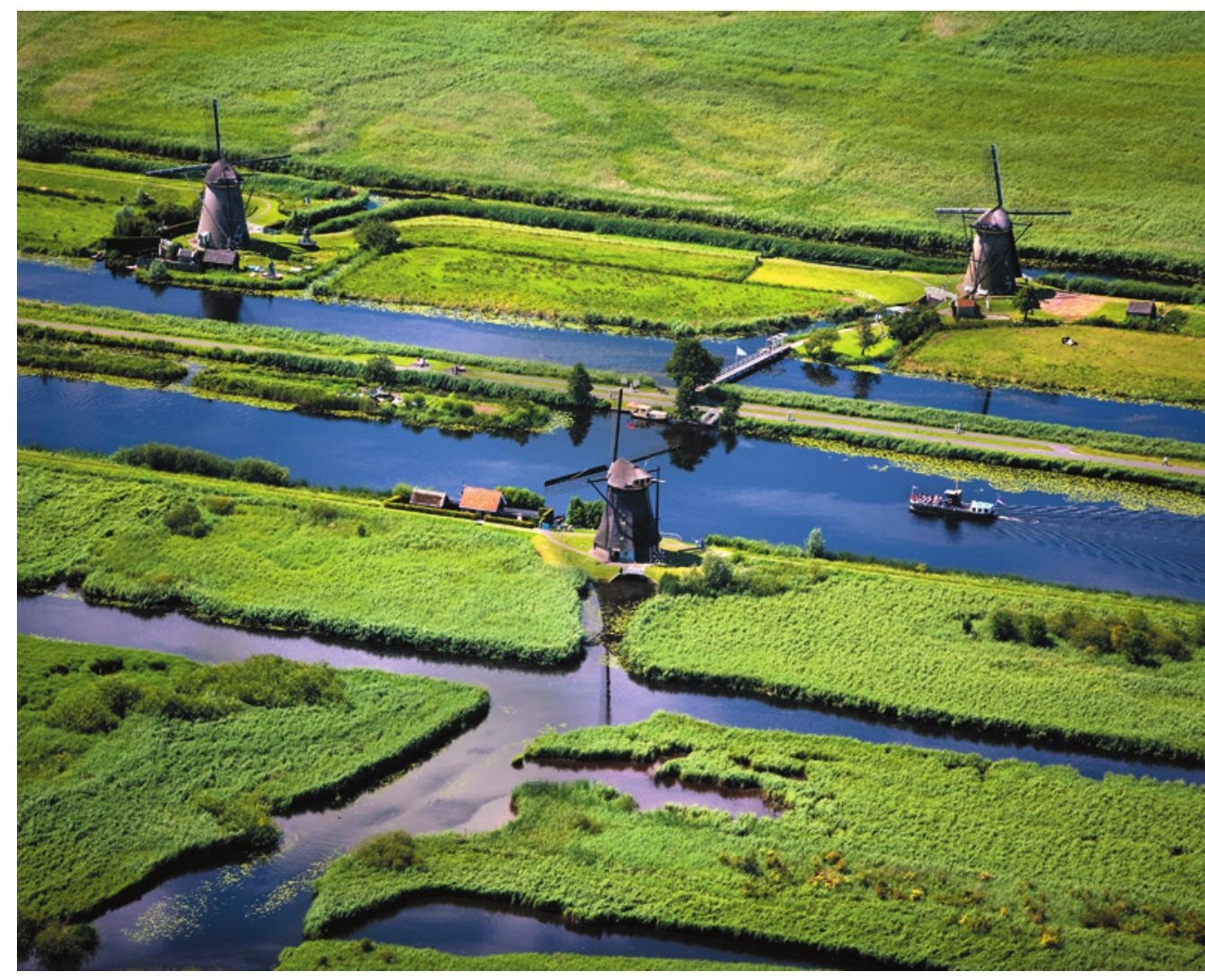

In the Netherlands, concerns about rising sea levels have led citizens to sue to force emissions cuts.

POLICY

\title{
Courts weigh in on climate change
}

\section{Successful Dutch climate litigation may encourage action across Europe, but US courts seem unlikely to follow suit.}

\section{BY QUIRIN SCHIERMEIER}

A group of Dutch citizens weary of ineffectual climate diplomacy are celebrating after forcing change through legal action. Last week, following a lawsuit filed by a citizens' climate-change platform called the Urgenda Foundation, a court in The Hague ordered the government of the Netherlands to cut greenhouse-gas emissions to at least 25\% below 1990 levels by 2020 - substantially greater cuts than are required under the small country's European Union (EU) obligations.

The ruling could encourage citizens of other countries to try using legal avenues to force stricter climate policies, says James Thornton, the London-based chief executive of Client Earth, an international group of environmental lawyers. "This is a very powerful decision with possible far-reaching repercussions," he says. "It is forcing the use of undisputed scientific results for responsible policy-making - a very remarkable step."

The Dutch government may still appeal the ruling, and even if it does have to implement extra emissions cuts, these would barely dent global greenhouse-gas emissions. But the court made clear that although Dutch policy-makers can do little to reduce emissions in China or the United States, they still have an obligation to act out of a duty of care for their citizens.

Thornton hopes that other courts will judge similar lawsuits in the same way in future. One such case is pending in Belgium, which must reduce its emissions by only $15 \%$ below 2005 levels under current EU pledges. But it is unclear whether the landmark Dutch ruling, and any European lawsuits that might follow, 
will make waves in other parts of the world particularly in the United States.

In 2007, the US Supreme Court authorized the Environmental Protection Agency (EPA) to regulate greenhouse-gas emissions that contribute to air pollution, because pollution could endanger public health or welfare. A series of greenhouse-gas reduction plans have followed. But attempts to get federal courts to order more-substantial cuts have so far come to nothing. Four years after the EPA decision, the Supreme Court rejected an effort by California and five other states to seek a cap on emissions from the utilities sector. The states argued that greenhouse gases are a 'public nuisance'; however, the court countered that the EPA's authority to regulate emissions prevented federal judges from using the public-nuisance argument. Attempts by others to claim liability against polluters and seek damages under civil law have also been unsuccessful.

\section{LIMITED POWER}

In the United States, "there is no federal constitutional right to environmental protection", says Richard Stewart, an environmental-law specialist at New York University. "Some state courts may recognize such a right, but the remedy might at best be limited to local sources."

That seems to be the case in Washington state, where on 23 June, a Seattle court ordered

the state's ecology department to reconsider a 2014 petition brought by eight school students to limit the state's carbon dioxide emissions. The petition called for the agency to act in line with what scientific evidence says is needed to protect the climate and the environment. The agency initially denied the petition, but has been ordered to report back to the court by 8 July. Petitioners' lawyer Andrea Rodgers, of the Western Environmental Law Center in

\section{"This is a very powerful decision with far-reaching repercussions." \\ Seattle, said that it was the first time a US court had ordered a state agency to con- sider the most current and best available cli- mate science in decid-}

ing regulation on carbon emissions.

It would be unusual for a US court to demand a specific level of federal emissions regulation, as has happened in the Netherlands, says Michael Oppenheimer, who studies geosciences and international affairs at Princeton University in New Jersey. A court would be likely to do so only if there were a large gap between public safety and existing regulations, he says.

"If it became clear that US regulations, along with actions of other countries, are insufficient, then at some future date a court might invoke the objective to force stronger action," he says. But, adds Oppenheimer, current US targets are consistent with "at least some pathways" that would keep the world's warming below $2{ }^{\circ} \mathrm{C}$, the internationally recognized threshold for 'dangerous' climate change.

\section{CORRECTIONS}

The News story 'Election results delight scientists' (Nature 522, 264-265; 2015) stated that Gençay Gürsoy won a seat in the new Turkish parliament for the HDP. He did not; he is a member of the HDP assembly.

The News story 'Earth science wrestles with conflict-of-interest policies' (Nature 522, 403-404; 2015) erroneously stated that hydrologist Donald Siegel disclosed the provision of water samples by Chesapeake Energy Corporation only in a correction to his article. In fact, this information was included in the acknowledgements of his original paper.

\section{CLARIFICATION}

The News story 'Earth science wrestles with conflict-of-interest policies' (Nature 522, 403-404; 2015) did not make clear that Siegel's findings related to gas production in general, and not just the process known as fracking. This has been clarified in the online version of the story. 